\title{
Pengaruh Perilaku Oportunistik, Asimetri Informasi, Moralitas Manajemen dan Kesesuaian Kompensasi Pada Praktik Kecurangan Akuntansi
}

\author{
Ni Made Dwi Prawitasari1 \\ Fakultas Ekonomi dan Bisnis \\ Universitas Udayana, Indonesia. \\ Email: dwiiprawita2@gmail.com
}

\author{
I Made Pande Dwiana Putra2 \\ Fakultas Ekonomi dan Bisnis \\ Universitas Udayana, Indonesia.
}

\begin{abstract}
ABSTRAK
Tujuan penelitian ini adalah melihat pengaruh perilaku oportunistik, asimetri informasi, moralitas manajemen, dan kesesuaian kompensasi pada praktik kecurangan akuntansi di Pemerintah Daerah Kabupaten Jembrana. Metode pengumpulan data yang digunakan adalah menggunakan kuesioner yang disebarkan langsung kepada staf keuangan di OPD Kabupaten Jembrana. Teknik analisis data yang digunakan adalah analisis regresi linear berganda.Berdasarkan hasil analisis regresi linear berganda ditemukan bahwa tingginya perilaku oportunistik dan tingginya asimetri informasi meningkatkan terjadinya kecurangan akuntansi di OPD Kabupaten Jembrana. Namun dengan semakin baiknya kesesuaian kompensasi akan menurunkan perilaku kecurangan akuntansi.
\end{abstract}

Kata Kunci : Perilaku oportunistik, asimetri informasi, moralitas manajemen, kesesuaian kompensasi.

\section{Opportunistic, Information Asymmetry, Management Morality and Compensation Compliance with Accounting Fraud Practices}

\begin{abstract}
The purpose of this study was to look at the effect of opportunistic behavior, information asymmetry, management morality, and compensation suitability for accounting fraud practices in the Regional Government of Jembrana Regency. This research was conducted at the Jembrana Regional District Government. The number of samples taken was 108 people, using the purposive sampling method. The data analysis technique used is multiple linear regression analysis. Based on the results of multiple linear regression analysis found that high opportunistic behavior and high information asymmetry increase the occurrence of accounting fraud in the Jembrana Regency OPD. However, the better suitability of compensation will reduce accounting fraudulent behavior.
\end{abstract}

Keywords: Opportunistic behavior, information asymmetry, management morality, conformity compensation.

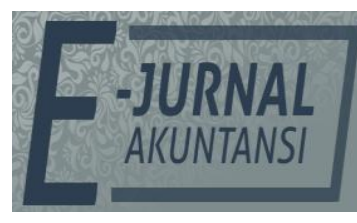

E-JA

e-Jurnal Akuntansi e-ISSN 2302-8556

Denpasar, Vol. 28 No. 3 September 2019 Hal. 1984-2000

Artikel masuk: 25 Juni 2019

Tanggal diterima: 05 Agustus 2019 


\section{PENDAHULUAN}

Kecenderungan kecurangan akuntasi di Indonesia saat ini marak terjadi, hal tersebut menjadi perhatian berbagai media di Indonesia maupun di dunia. Kecenderungan adanya kecurangan akuntansi bisa terjadi dimana saja tidak terkecuali dalam suatu pemerintahan. Terdapat opini bahwa kecurangan akuntansi dapat dikatakan sebagai tendensi korupsi dalam definisi dan terminologi karena keterlibatan beberapa unsur yang terdiri dari pengungkapan fakta-fakta menyesatkan, pelanggaran aturan, atau penyalahgunaan kepercayaan (Soepardi, 2007). Indikasi adanya kecurangan akuntansi dapat dilihat dari bentuk kebijakan maupun tindakan yang disengaja dengan tujuan untuk melakukan penipuan atau manipulasi yang dapat merugikan banyak pihak lain.

Tindakan kecurangan (fraud) telah memunculkan beberapa kasus skandal pelaporan akuntansi yang secara luas diketahui, antara lain Enron, Merck, Worldcom, dan mayoritas perusahaan lain di Amerika Serikat. Kasus mengenai manajemen laba juga sudah banyak terjadi di Indonesia, seperti pada PT Lippo Tbk dan PT Kimia Farma Tbk dimana melibatkan pelaporan keuangan (financial reporting) yang berawal dari adanya manipulasi. Kasus lain terkait (fraud) menjerat perusahaan Personal Computer (PC) Jepang di Indonesia yakni PT Toshiba Customer Product Indonesia mengalami skandal terkait praktik fraud yang dilakukan pihak manajemen di tahun 2015, dan PT Indofarma Tbk pada tahun 2001. Contoh kasus lainnya terjadi pada Citibank yaitu pembobolan dana nasabah yang dilakukan karyawan senior yang kala itu menjabat sebagai vice president di bank tersebut dan juga karyawan Citibank yang bertugas sebagai teller yang terjadi pada Maret 2011(Putra, 2011).

Kasus dan masalah kecurangan laporan akuntansi tidak hanya terjadi pada perusahaan-perusahaan besar seperti contoh yang dipaparkan sebelumnya. Kasus kecurangan juga terjadi di dalam tubuh pemerintahan. Pemerintah Provinsi Bali khususnya mencatat di tahun 2017 telah diterbitkan sembilan laporan hasil penghitungan kerugian keuangan negara di setiap kabupaten dengan tiga di antaranya memiliki nilai kerugian yang lebih tinggi dibanding kabupaten lain, dapat dilihat pada Tabel 1.

Tabel 1. Jumlah Kerugian Keuangan Negara Pemerintah Provinsi Bali Tahun 2017 (dalam Ribuan Rupiah)

\begin{tabular}{llrrrr}
\hline No & Kabupaten & $\begin{array}{c}\text { Jumlah } \\
\text { Kasus }\end{array}$ & Nilai Kerugian & $\begin{array}{c}\text { PAD } \\
\text { Kabupaten }\end{array}$ & $\begin{array}{c}\text { Persentase } \\
\text { Perbandingan } \\
\text { nilai }\end{array}$ \\
\hline 1. & Denpasar & 1 & 2.853 .766 & 1.008 .710 .712 & $0,28 \%$ \\
2. & Tabanan & 1 & 200.000 & 426.635 .751 & $0,05 \%$ \\
3. & Bangli & 1 & 134.414 & 104.592 .163 & $0,13 \%$ \\
4. & Klungkung & 1 & 94.344 & 153.210 .776 & $0,06 \%$ \\
5. & Jembrana & 3 & 1.065 .800 & 121.342 .475 & $0,89 \%$ \\
6. & Badung & 1 & 952.200 & 4.172 .457 .396 & $0,02 \%$ \\
\hline
\end{tabular}

Sumber: www.bpkp.go.id/bali.bpkp, 2018

Dapat dilihat pada Tabel 1 bahwa ternyata dari sembilan pusat pemerintahan daerah di Bali, Kabupaten Jembrana memiliki jumlah kasus kecurangan tertinggi di tahun 2017. Tercatat jumlah kasus di Pemerintahan 
Daerah Kabupaten Jembranamencapai tiga kasus. Nilai kerugian yang dihasilkan dari kasus kecurangan di Kabupaten Jembrana mencapai Rp 1.065.800.000.

Pada Tabel 1 juga menjelaskan nilai Pendapatan Asli Daerah (PAD) serta kerugian negara yang dilakukan tiap kabupaten. Hasil pada tabel menunjukkan bahwa PAD Kabupaten Jembrana berada pada posisi terendah kedua dibanding pemerintah daerah lain sementara kerugian negara yang dialami Kabupaten Jembrana menduduki posisi tertinggi kedua dibandingkan dengan kabupaten lain. Perhitungan persentase perbandingan nilai kerugian dan PAD menunjukkan Kabupaten Jembrana menjadi posisi tertinggi dengan nilai persentase sebesar $0,89 \%$. Hal ini menegaskan tingginya nilai kerugian yang dialami Kabupaten Jembrana khususnya di tahun 2017.

Sejak tahun 2008 hingga saat ini, pembangunan di Kabupaten Jembrana terus meningkat dari berbagai aspek. Hal tersebut dapat dilihat dari perkembangan Kabupaten Jembrana yang mencapai kesuksesan di beberapa hal, antara lain pendapatan asli daerah yang meningkat drastis, dari tahun 2000 yang berkisar 1 milyar rupiah hingga pada tahun 2006 menjadi 11 milyar rupiah, sudah sepenuhnya melaksanakan E-government dengan memakai open source software, layanan pemerintah yang efisien, satu loket, cepat, dan anti korupsi. Program-program kerja yang dicanangkan Kabupaten Jembrana juga mencapai kesuksesan meliputi program pendidikan gratis, pengobatan gratis, KTP, kartu kelahiran gratis, serta terdapat asuransi kematian, Pajak Bumi dan Bangunan (PBB) sawah gratis (Pradana, 2014).

Terlepas dari prestasi yang ada, Kabupaten Jembrana merupakan kabupaten dengan kasus kecurangan terbanyak seperti yang disajikan pada Tabel 1. dimana kerugian negara mencapai Rp 1.065.800.000. Kasus terbaru juga terjadi di tahun 2015 dengan adanya kasus penyalahgunaan dana bantuan santunan kematian masyarakat Kabupaten Jembrana yang menimbulkan kerugian keuangan negara sebesar Rp 451.000.000. Kasus ini bermula dari adanya kecurigaan keterlibatan oknum PNS Pemerintah Kabupaten Jembrana dengan bantuan dari enam mantan aparat desa / kelurahan. Tindakan korupsi dana santunan kematian tahun 2015, terungkap dilakukan dengan dua cara. Pertama adalah dengan merekayasa data kematian warga. Kedua adalah dengan mengajukan kembali data kematian warga yang dulu sudah pernah mendapat dana santunan kematian, sehingga terjadi pencairan ganda. Sesuai dengan Peraturan Bupati Jembrana Nomor 1 tahun 2014 bahwa setiap warga Jembrana yang meninggal hanya sekali mendapatkan dana santunan kematian dengan nilai $\operatorname{Rp} 1.500 .000$.

Praktik-praktik kecurangan akuntansi ini berlawanan dengan akuntabilitas. Laporan keuangan pemerintah merupakan representasi posisi keuangan dari transaksi-transaksi yang dilakukan oleh pemerintah. (Pradana, Adiputra, 2014)menyatakan bahwa dimensi akuntabilitas publik meliputi akuntabilitas hukum dan kejujuran, akuntabilitas manajerial, akuntabilitas program, akuntabilitas kebijakan dan akuntabilitas finansial (keuangan). Terkait dengan tugas untuk menegakkan akuntabilitas finansial khususnya di daerah, pemerintah daerah memiliki tanggung jawab untuk mempublikasikan laporan keuangan kepada pemangku kepentingannya (stakeholder). 
Penyimpangan-penyimpangan laporan keuangan menyebabkan informasi yang ada dalam laporan keuangan menjadi tidak relevan dan tidak dapat diandalkan. Tindakan dalam kecurangan akuntansi adalah tindakan yang menyebabkan kesalahan pelaporan dalam laporan keuangan, atau suatu tindakan kesengajaan untuk menggunakan sumber daya perusahaan secara wajar dan salah menyajikan fakta untuk memperoleh keuntungan pribadi.

Kecurangan akuntansi sering kali diidentikkan dengan perilaku oportunistik. Eisenhardt, (1989) menyatakan bahwa teori agensi menggunakan tiga asumsi sifat manusia, yaitu manusia pada umumya mementingkan diri sendiri (self interest), manusia memiliki daya pikir terbatas mengenai persepsi masa mendatang (bounded rationality), dan manusia selalu menghindari risiko (risk averse). Berdasarkan asumsi sifat dasar manusia tersebut pejabat sebagai manusia akan bertindak oportunistik, yaitu mengutamakan kepentingan pribadinya. Tindakan oportunis tersebut dilakukan dengan cara memilih kebijakan akuntansi tertentu sehingga laba organisasi dapat diatur, dinaikkan atau diturunkan sesuai dengan keinginannya (Putra, 2011).

Kecurangan akuntansi dalam organisasi juga dapat terjadi karena adanya asimetri informasi. Asimetri informasi mengandung arti bahwa agen memiliki informasi yang tidak dimiliki oleh pihak prinsipal. (Lestari \& Supadmi, 2017) menyatakan bahwa asimetri informasi yang terjadi antara prinsipal dan agen mendorong agen untuk menyajikan informasi yang tidak sebenarnya, terutama jika informasi tersebut berkaitan dengan pengukuran kinerja agen. Penelitian yang dilakukan oleh Wilopo, (2006) dan Mustikasari, (2013) menunjukkan bahwa asimetri informasi berpengaruh signifikan terhadap kecurangan. Hal ini sejalan dengan penelitian yang dilakukan oleh (Lestari \& Supadmi, 2017) yang menunjukkan bahwa asimetri informasi mempunyai pengaruh positif dan signifikan terhadap kecurangan akuntansi.

Mencapai tujuan good governance tidak terlepas dari peran individu yang tergabung dalam organisasi. Mencapai tujuan yang telah ditetapkan tentu diperlukan perencanaan dan pengelolaan sumber daya manusia sebaik-baiknya. Sumber daya manusia merupakan hal terpenting yang dimiliki suatu organisasi, salah satu implikasinya yaitu bahwa investasi terpenting yang dilakukan oleh suatu organisasi adalah di bidang sumber daya manusia (Handoko, 2014).

Kecurangan akuntansi juga disebabkan oleh beberapa hal yang substansial seperti sikap dan tanggung jawab moral perusahaan. Perusahaan memiliki tanggung jawab moral dan sosial yang pada tingkat operasional, tanggung jawab moral ini diwakili oleh manajemen. Kecenderungan kecurangan akuntansi yang dilakukan oleh manajemen perusahaan juga tergantung pada moralitas manajemen, sehingga segala tindakan yang dilakukan oleh manajemen mencerminkan moralitasnya. Semakin tinggi tahapan moralitas manajemen (tahapan postkonvensional), semakin manajemen memperhatikan kepentingan yang lebih luas dan universal daripada kepentingan perusahaan/instansi semata, terlebih kepentingan pribadinya (Keraf, 1998).

Kesesuaian kompensasi merupakan salah satu faktor yang mempengaruhi adanya kecurangan akuntasi. Kompensasi lazim disebut sebagai penghargaan dan dapat didefinisikan sebagai setiap bentuk penghargaan yang diberikan kepada karyawan sebagai balas jasa atas kontribusi yang mereka berikan kepada 
organisasi (Dito, 2010). Kompensasi yang sesuai mengurangi adanya perilaku kecurangan. Individu diharapkan telah mendapatkan kepuasan dari kompensasi tersebut dan tidak berlaku curang dalam akuntansi untuk memaksimalkan keuntungan sendiri.

Berdasarkan latar belakang yang telah dikemukakan maka peneliti tertarik untuk melakukan penelitian lebih jauh mengenai kecenderungan kecurangan akuntansi yang ditinjau dari perilaku oportunistik, asimetri informasi, moralitas manajemen dan kesesuaian kompensasi. Lokasi penelitian akan dilakukan di Pemerintah daerah Kabupaten Jembrana. Penelitian ini dilakukan dengan menggali persepsi para pegawai pengelola keuangan pada Organisasi Perangkat Daerah (OPD) Kabupaten Jembrana untuk mengetahui kecenderungan kecurangan akuntansi dan faktor-faktor yang mempengaruhinya.

Perilaku oportunistik merupakan perilaku individu untuk berusaha mengambil keuntungan bagi diri sendiri tanpa mempedulikan prinsip - prinsip yang berlaku. Perilaku oportunistik dapat juga digolongkan sebagai perilaku yang cenderung memanipulasi informasi. Individu dengan perilaku oportunistik secara signifikan dapat memanipulasi informasi dan data yang ada sehingga hal ini bertentangan dengan hak setiap orang untuk mendapatkan informasi yang akurat (Yakovleva et al 2016). Fajri \& Senja (2006) menyatakan bahwa opportunism adalah pandangan yang semata-mata hendak mengambil keuntungan untuk memperkaya diri sendiri dari kesempatan yang ada tanpa berpegang pada prinsip yang berlaku. Perilaku opportunistic adalah perilaku yang senantiasa hendak mengambil keuntungan dari setiap kesempatan yang ada tanpa berpegang pada prinsip yang berlaku.

Teori keagenan menggunakan tiga asumsi sifat manusia yaitu manusia pada umumya mementingkan diri sendiri (self interest), manusia memiliki daya pikir terbatas mengenai persepsi masa mendatang (bounded rationality), dan manusia selalu menghindari risiko (risk averse). Berdasarkan pada asumsi sifat dasar manusia tersebut manajer sebagai manusia akan bertindak oportunistik, yaitu akan lebih mengutamakan kepentingan bagi dirinya sendiri (Eisenhardt, 1989).

Perilaku oportunistik pemerintah dalam proses penyusunan suatu anggaran biasanya dilakukan oleh pihak-pihak yang terlibat dalam penyusunan anggaran. Suatu kecurangan muncul karena adanya peluang untuk mendapatkan keuntungan pribadi pada proyek-proyek yang akan di biayai dengan anggaran. Perilaku oportunistik didukung oleh teori keagenan dimana bila agen dan principal berusaha untuk memaksimalkan utilitasnya masingmasing, serta memiliki keinginan dan motivasi berbeda, maka agen akan cenderung tidak selalu bertindak sesuai dengan principal. Penelitian Prakasa (2016) menemukan bahwa perilaku oportunistik berpengaruh positif terhadap kecenderungan kecurangan akuntansi, Sari \& Meiranto (2017) menemukan hasil yang sama yaitu adanya pengaruh positif perilaku oportunistik terhadap peningkatan perilaku kecurangan akuntansi.

$\mathrm{H}_{1}$ : Perilaku oportunistik berpengaruh positif pada kecurangan akuntansi. 
Teori keagenan bermaksud memecahkan dua masalah yang terjadi dalam hubungan keagenan. Salah satunya adalah masalah yang muncul bila keinginan atau tujuan principal dan agen bertentangan, dan juga disaat principal merasa kesulitan untuk menelusuri apa yang sebenarnya dilakukan oleh agen.

Asimetri informasi terjadi ketika hanya pihak internal instansi yang mengetahui isi dan angka yang sebenarnya dari laporan keuangan yang disusun (Najahningrum, 2013). Kesenjangan informasi antara pihak pengelola dan pihak pemakai berkaitan dengan pembuatan laporan keuangan instansi publik. Hal ini berkaitan dengan kurangnya transparansi atau keterbukaan antara pihak pengelola keuangan dan pihak masyarakat yang memperoleh informasi tersebut.

Hubungan antara principal dan agent menurut teori keagenan dapat mengarah pada kondisi ketidakseimbangan informasi karena agen berada pada posisi yang memiliki informasi yang lebih banyak tentang perusahaan dibandingkan dengan principal. Dengan asumsi bahwa individu-individu bertindak untuk memaksimalkan kepentingan diri sendiri, maka dengan asimetri informasi yang dimilikinya akan mendorong agen untuk menyembunyikan beberapa informasi yang tidak diketahui principal. Agen dapat mempengaruhi angka-angka akuntansi yang disajikan dalam laporan keuangan dengan cara memanipulasi (Setiawan \& Adiputra, 2015).

Asimetri informasi merupakan ketidakseimbangan informasi yang dimiliki oleh principal dan agen, ketika principal tidak memiliki informasi yang cukup tentang kinerja agen, sebaliknya justru agen memiliki lebih banyak informasi mengenai kapasitas diri, lingkungan kerja dan instansi secara keseluruhan (Ariani \& Musmini, 2014). Hal ini membuat manajemen (agen) berpikir untuk mengubah angka akuntansi agar dapat digunakan untuk memaksimalkan kepentingannya. Menurut (Ariani \& Musmini, 2014) menyatakan bahwa asimetri informasi berpengaruh positif terhadap kecurangan akuntansi. Najahningrum (2013) menyatakan bahwa apabila terjadi kesenjangan informasi antara pihak pengguna dan pihak pengelola, maka akan membuka peluang bagi pihak pengelola dana untuk melakukan kecurangan. Hal tersebut dapat diatasi jika kedua belah pihak bisa mengatur kembali kontrak yang disepakati dalam rangka memberikan motivasi agar dapat mengikuti prosedur kerja dan aturan akuntansi yang berlaku. Penelitian Najahningrum (2013) menunjukkan bahwa asimetri informasi berpengaruh positif terhadap kecurangan akuntansi.

Sisi lain penelitian terdahulu menemukan hasil yang berbeda. Penelitian Alou et al, (2017) yang juga menemukan bahwa tidak adanya pengaruh moralitas manajemen terhadap tindak kecurangan akuntansi yang dilakukan pada perusahaan konstruksi. Penelitian ini juga didukung Sholehah et al., (2018) menemukan bahwa moralitas manajemen tidak memiliki pengaruh yang signifikan terhadap tindakan fraud yang dilakukan pada OPD Provinsi Gorontalo.

Berdasarkan hasil penelitian sebelumnya, maka hipotesis yang diajukan peneliti sebagai berikut:

$\mathrm{H}_{2}$ : Asimetri informasi berpengaruh positif pada kecurangan akuntansi. 
Teori agensi menyebutkan bahwa adanya perilaku dari manajer/agen yang bertindak hanya untuk menguntungkan dirinya sendiri dengan mengorbankan kepentingan orang lain. Hal ini tidak sesuai dengan kematangan moral manajemen baik diperusahaan maupun di pemerintahan yang menjadi indikasi pembuatan keputusan. Manajemen merupakan kumpulan individu yang juga memiliki tahapan moral. Pada tahap konvensional, pertimbangan moral didasarkan atas pemahaman aturan sosial, hukum-hukum, keadilan dan kewajiban. Manajemen dalam tahap ini mulai membentuk moralitas manajemennya dengan menaati peraturan lalu terbentuk kematangan moral manajemen yang tinggi pada tahap pasca-konvensional. Manajemen pada tahapan post konvensional menunjukkan kematangan moral manajemen yang tinggi. Kematangan moral menjadi dasar dan pertimbangan manajemen dalam merancang tanggapan dan sikap terhadap isu-isu etis.

Manajemen dengan moralitas yang tinggi diharapkan tidak melakukan tindakan-tindakan yang menyimpang dan melakukan kecurangan akuntansi demi memaksimalkan keuntungan pribadi. (Maroney \& McDevitt, 2008) menemukan bahwa adanya interaksi yang signifikan antara level moral dari partisipan dengan pelaporan yang dibuat. Level moral yang rendah secara signifikan berasosiasi dengan rendahnya ketepatan perhitungan laporan keuangan yang dibuat. (Rahmawati, 2012) menemukan bahwa semakin tinggi moralitas suatu manajemen berpengaruh negatif signifikan terhadap kecenderungan kecurangan akuntansi. Perkembangan pengetahuan moral menjadi indikasi pembuatan keputusan secara etis. Manajemen dengan moralitas yang tinggi diharapkan tidak melakukan tindakan-tindakan yang menyimpang dan melakukan kecurangan akuntansi demi memaksimalkan keuntungan pribadi. Penelitian lain juga menemukan bahwa moralitas manajemen berpengaruh negatif terhadap kecurangan akuntansi pada BUMN Padang (Sanuari, 2014). Safitri (2017) juga menemukan adanya pengaruh negatif moralitas manajemen terhadap kecurangan akuntansi pada pegawai BUMN di Daerah Istimewa Yogyakarta.

Sisi lain penelitian terdahulu menemukan hasil yang berbeda. Penelitian (Alou et al., 2017) yang juga menemukan bahwa tidak adanya pengaruh moralitas manajemen terhadap tindak kecurangan akuntansi yang dilakukan pada perusahaan konstruksi. Astuti (2017) menemukan bahwa moralitas tidak berpengaruh terhadap kecederungan kecurangan akuntansi yang terjadi pada LPD di Kabupaten Buleleng. Penelitian lain yang juga mendukung Sholehah et al., (2018) menemukan bahwa moralitas manajemen tidak memiliki pengaruh yang signifikan terhadap tindakan fraud yang dilakukan pada OPD Provinsi Gorontalo.

Berdasarkan uraian diatas adanya inkonsistensi dari hasil penelitianpenelitian sebelumnya, maka hipotesis yang diajukan peneliti sebagai berikut:

$\mathrm{H}_{3}$ : Moralitas manajemen berpengaruh negatif pada kecurangan akuntansi.

Dalam teori atribusi, suatu tindakan seseorang dalam organisasi dipengaruhi oleh atribut penyebab (Waworuntu, 2003). Teori keagenan dalam Astrid (2015) menjelaskan bahwa pemberian kompensasi yang memadai membuat agen (manajemen) bertindak sesuai dengan keinginan dari principal yaitu dengan memberikan suatu informasi sebenarnya tentang keadaan 
perusahaan. Kompensasi yang diterima karyawan harus sesuai dengan kontribusi yang diberikan karyawan kepada organisasi. Pemberian kompensasi yang sesuai kepada karyawan dapat memberikan kepuasan dan motivasi kepada karyawan dalam bekerja, sehingga mendorong mereka untuk memberikan yang terbaik bagi perusahaan tempat mereka bekerja.

Hal ini juga dapat meminimalkan tindakan karyawan untuk melakukan kecurangan akuntansi melalui pencurian aset atau penipuan lainnya karena kesejahteraan karyawan diperhatikan dengan baik oleh perusahaan melalui pemberian kompensasi yang sesuai dan adil. Program kompensasi harus ditetapkan atas prinsip keadilan dan kelayakan/kesesuaian untuk mendukung antara kepentingan organisasi dan karyawan. Pernyataan tersebut didukung oleh penelitian sebelumnya yang dilakukan oleh Shintadevi (2016) dan Delfi et al, (2014) yang menyatakan bahwa kesesuaian kompensasi berpengaruh negatif terhadap kecenderungan kecurangan akuntansi. Oktavia et al., (2016) juga menemukan bahwa adanya pengaruh negatif dari kompensasi terhadap kecurangan akuntansi yang terjadi pada instansi. Berdasarkan hal yang telah diuraikan, maka hipotesis yang diajukan peneliti sebagai berikut.

$\mathrm{H}_{4}$ : Kesesuaian kompensasi berpengaruh negatif pada kecurangan akuntansi.

\section{METODE PENELITIAN}

Penelitian ini dilakukan di Kabupaten Jembrana dengan subjek penelitian adalah OPD yang terdapat di Kabupaten Jembrana. Dasar pertimbangan penelitian ini dilakukan pada Pemerintahan Kabupaten Jembrana karena berdasarkan dari Laporan Hasil Pengawasan Semester II 2017 yang dilakukan oleh Perwakilan Badan Pengawas Keuangan dan Pembangunan (BPKP) Provinsi Bali, Kabupaten Jembrana merupakan kabupaten dengan jumlah kasus kerugian keuangan terbanyak yaitu sebanyak tiga kasus.

Populasi yang digunakan dalam penelitian ini adalah pegawai OPD Kabupaten Jembrana. Jumlah populasi sebesar 872. Teknik pengambilan sampel yang digunakan dalam penelitian ini adalah teknik purposive sampling.Responden diambil sebanyak 6 orang dari masing-masing Dinas/ Badan yang terdiri oleh staf bendahara, staf verifikasi, staf input SPP (Surat Permintaan Pembayaran), staf input SPM (Surat Perintah Membayar), staf input SPJ (Surat Pertanggungjawaban), dan staf akuntansi dan pelaporan sesuai dengan kriteria.

Cara mengetahui pengaruh perilaku oportunistik, asimetri informasi, moralitas manajemen dan kesesuaian kompensasi terhadap kecenderungan kecurangan akuntansi pada Pemerintah Daerah Kabupaten Jembrana, makadigunakan model analisis regresi linear berganda. Analisis ini bertujuan untuk menguji pengaruh antara variabel bebas yaitu perilaku oportunistik, asimeri informasi, moralitas manajemen, kesesuaian kompensasi terhadap variabel terikat kecurangan akuntansi. Rumus dapat dilihat dalam persamaan berikut:

$Y=\alpha+\beta_{1} X_{1}+\beta_{2} X_{2}+\beta_{3} X_{3}+\beta_{4} X_{4}+e+$

Keterangan :

$\mathrm{Y}=$ Kecurangan akuntansi

$\alpha=$ Konstanta

$\beta_{1}=$ Koefisien regresi variabel perilaku oportunistik 
$\beta_{2}=$ Koefisien regresi variabel asimetri informasi

$\beta_{3}=$ Koefisien regresi variabel moralitas manajemen

$\beta_{4}=$ Koefisien regresi variabel kesesuain kompensasi

$\mathrm{X}_{1}=$ Perilaku oportunistik

$\mathrm{X}_{2}=$ Asimetri informasi

$\mathrm{X}_{3}=$ Moralitas manajemen

$\mathrm{X}_{4}=$ Kesesuaian kompensasi

$\mathrm{e}=$ Komponen residual atau error term.

Perhitungannya selanjutnya akan menggunakan alat bantu komputer dengan paket program statistik SPSS For Windows Versi 21.00.

\section{HASIL DAN PEMBAHASAN}

Statistik deskriptif adalah statistik yang digunakan untuk menganalisa data dengan cara mendeskripsikan data yang telah diperoleh sebagaimana adanya tanpa bermaksud membuat kesimpulan yang berlaku untuk umum atau generalisasi. Hasil statistik deskriptif penelitian ini menunjukkan data sebagai berikut:

\section{Tabel 2. Uji Statistik Deskriptif}

\begin{tabular}{|c|c|c|c|c|c|}
\hline Variabel & $\begin{array}{c}\text { Jumlah } \\
\text { Pernyata } \\
\text { an }\end{array}$ & $\begin{array}{l}\text { Min/ Jml } \\
\text { Pernyata } \\
\text { an }\end{array}$ & $\begin{array}{c}\text { Max/Jml } \\
\text { Pernyata } \\
\text { an }\end{array}$ & $\begin{array}{c}\text { Mean } / \mathrm{Jm} \\
1 \\
\text { Pernyata } \\
\text { an }\end{array}$ & $\begin{array}{c}\text { Std./Jml } \\
\text { Pernyataan }\end{array}$ \\
\hline $\begin{array}{l}\text { Perilaku } \\
\text { Oportunistik (X1) }\end{array}$ & 8 & 1 & 3 & 1,968 & 0,449 \\
\hline $\begin{array}{l}\text { Asimetri } \\
\text { informasi (X2) }\end{array}$ & 6 & 1 & 4 & 2,822 & 0,560 \\
\hline $\begin{array}{l}\text { Moralitas } \\
\text { Manajemen (X3) }\end{array}$ & 5 & 1 & 4 & 2,564 & 0,622 \\
\hline $\begin{array}{l}\text { Kesesuaian } \\
\text { Kompensasi (X4) }\end{array}$ & 10 & 1 & 4 & 2,573 & 0,459 \\
\hline $\begin{array}{l}\text { Kecurangan } \\
\text { akuntansi }(\mathrm{Y})\end{array}$ & 9 & 1 & 3 & 1,719 & 0,436 \\
\hline
\end{tabular}

Sumber: Data Penelitian, 2019

Berdasarkan Tabel 2 dapat dilihat bahwa variabel independen yang memiliki nilai rata-rata tertinggi yaitu variabel asimetri informasi dengan nilai 2,822 dan diikuti oleh variabel kesesuaian kompensasi dan moralitas manajemen yaitu masing-masing sebesar 2,573 dan 2,564. Variabel independen yang memiliki nilai terendah dari seluruh variabel independen yaitu adalah variabel perilaku oportunistik dengan nilai rata-rata yaitu 1,968.

Analisis regresi linier berganda (multiple linear regression) digunakan untuk menguji hipotesis yang ada, yaitu untuk melihat pengaruh perilaku oportunistik, asimetri informasi, moralitas manajemen, dan kesesuaian kompensasi terhadap kecurangan akuntansi. Hasil dari analisis regresi linear berganda dapat dilihat pada Tabel 3 berikut. 
Tabel 3. Hasil Analisis Regresi Linear Berganda

\begin{tabular}{lcccc}
\hline \multicolumn{1}{c}{ Variabel } & $\begin{array}{c}\text { Unstandardized } \\
\text { Coefficients }\end{array}$ & $\begin{array}{c}\text { standardized } \\
\text { Coefficients }\end{array}$ & t Hitung & Sig. \\
\hline Perilaku Oportunistik (X1) & 0,620 & 0,568 & 4,488 & 0,000 \\
Asimetri Informasi (X2) & 0,375 & 0,321 & 2,745 & 0,007 \\
Moralitas Manajemen (X3) & $-0,192$ & $-0,152$ & $-1,684$ & 0,095 \\
Kesesuaian Kompensasi (X4) & $-0,147$ & $-0,172$ & $-2,034$ & 0,045 \\
(Constant) & 5,611 & & 1,076 & 0,284 \\
R & 0,554 & & & \\
R Square & 0,307 & & & 0,000 \\
F Hitung & 11,401 & & & \\
Std. Error of the Estimate & 3,331 & & &
\end{tabular}

Sumber: Data Penelitian, 2019

Berdasarkan Tabel 3 maka didapatkan hasil persamaan sebagai berikut :

$$
\mathrm{Y}=5,611+0,620 \mathrm{X}_{1}+0,375 \mathrm{X}_{2}+-0,192 \mathrm{X}_{3}+-0,147 \mathrm{X}_{4}+\mathrm{e}
$$

Nilai koefisien regresi variabel perilaku oportunistik (X1) adalah 0,620. Nilai positif pada hasil nilai koefisien ini menunjukkan perilaku oportunistik (X1) bernilai positif, hal ini berarti perilaku oportunistik (X1) mempunyai pengaruh positif terhadap kecurangan akuntansi (Y), artinya jika pengaruh oportunistik (X1) meningkat satu satuan akan cenderung meningkatkan kecurangan akuntansi (Y) sebesar 0,620 satuan dengan asumsi variabel lainnya sama dengan nol.

Nilai koefisien regresi variabel asimetri informasi (X2) adalah 0,375. Nilai ini menunjukkan bahwa asimetri informasi (X2) bernilai positif, hal ini berarti adanya asimetri informasi (X2) mempunyai pengaruh positif terhadap kecurangan akuntansi $(\mathrm{Y})$, artinya jika ada pemanfaatan asimetri informasi (X2) meningkat satu satuan akan cenderung meningkatkan kecurangan akuntansi (Y) sebesar 0,375 satuan dengan asumsi variabel lainnya sama dengan nol.

Nilai koefisien regresi variabel moralitas manajemen (X3) adalah -0,192. Nilai ini menunjukkan variabel moralitas manajemen (X3) terhadap kecurangan akuntansi bernilai negatif, sehingga dapat diartikan moralitas manajemen (X3) memiliki pengaruh negatif terhadap kecurangan akuntansi (Y). Kesimpulannya ketika moralitas manajemen (X3) meningkat satu satuan cenderung menurunkan kecurangan akuntansi $(Y)$ sebesar -0,192 satuan dengan asumsi variabel lainnya sama dengan nol.

Nilai koefisien regresi variabel kesesuaian kompensasi (X4) adalah -0,147. Nilai ini menunjukkan kesesuaian kompensasi (X4) bernilai negative terhadap kecurangan akuntansi atau dapat diartikan kesesuaian kompensasi (X4) mempunyai pengaruh negatif terhadap kecurangan akuntansi (Y). Kesimpulannya bahwa ketika kompensasi (X4) meningkat satu satuan cenderung menurunkan kecurangan akuntansi (Y) sebesar -0,147 satuan dengan asumsi variabel lainnya sama dengan nol.

Analisis determinasi digunakan sebagai alat untuk mengetahui besarnya persentase hubungan atau pengaruh variabel independen (perilaku oportunistik, asimetri informasi, moralitas manajemen, kesesuaian kompensasi) terhadap variabel dependen (kecurangan akuntansi), yang dinyatakan dalam persentase. Berdasarkan data pada Tabel 3 diperoleh angka $\mathrm{R}^{2}$ sebesar 0,307 atau 30,7\%. Hal ini menunjukkan bahwa 30,7\% variabel dependen (kecurangan akuntansi) 
dipengaruhi oleh variabel independen (perilaku oportunistik, asimetri informasi, moralitas manajemen, kesesuaian kompensasi), sedangkan sisanya sebesar 69,3\% dipengaruhi atau dijelaskan oleh variabel lain yang tidak dimasukkan dalam penelitian ini.

Uji kelayakan model bertujuan untuk mengetahui apakah model regresi layak digunakan dengan menggunakan uji simultan (uji F). Pengujian dilakukan dengan menggunakan tingkat keyakinan 95\% dengan taraf kesalahan (a) yang digunakan yaitu $5 \%$ atau0,05 $(\alpha=5 \%)$. Ketentuan model regresi dinyatakan layak apabila signifikasi $\mathrm{F}_{\text {hitung }}<\mathrm{a}(0,05)$.

Berdasarkan Tabel 3 menunjukkan bahwa nilai signifikan kurang dari 0,05 $(0,000<0,05)$, hal ini menunjukkan bahwa model regresi dengan variabel independen yaitu perilaku oportunistik, asimetri informasi, moralitas manajemen, dan kesesuaian kompensasi dan variabel dependen yaitu kecurangan akuntansi.

Uji hipotesis digunakan untuk menguji seberapa jauh pengaruh satu variabel independen secara individual dalam menerangkan variabel dependen. Cara untuk mengetahui hasil uji hipotesis adalah dengan melihat hasil regresi yang dilakukan dengan program SPSS, yaitu dengan melihat nilai $\mathrm{t}$ hitung, kemudian membandingkan tingkat signifikansi variabel bebas dengan $\alpha=0,05$ atau $5 \%$, dan membandingkan nilai $\beta$.

Berdasarkan Tabel 3 dapat dilihat bahwa variabel perilaku oportunistik memiliki nilai $\beta_{1}$ positif lebih besar daripada nol sebesar 0,620 dengan nilai signifikansi lebih kecil dari 0,05 sebesar 0,000 . Nilai tersebut menunjukkan $\mathrm{H}_{1}$ diterima, yang artinya perilaku oportunistik berpengaruh positif dan signifikan terhadap kecurangan akuntansi.

Variabel asimetri informasi memiliki nilai $\beta_{2}$ positif lebih besar daripada nol sebesar 0,375 dengan nilai signifikansi lebih kecil dari 0,05 sebesar 0,007. Nilai tersebut menunjukkan $\mathrm{H}_{2}$ diterima, yang artinya pemanfaatan asimetri informasi berpengaruh positif dan signifikan terhadap kecurangan akuntansi.

Variabel moralitas manajemen memiliki nilai $\beta_{3}$ negatif lebih besar daripada nol sebesar -0,192 dengan nilai signifikansi lebih besar dari 0,05 yaitu sebesar 0,095. Nilai tersebut menunjukkan bahwa $\mathrm{H}_{3}$ ditolak, yang artinya moralitas manajemen tidak berpengaruh negatif dan signifikan terhadap kecurangan akuntansi.

Variabel kesesuaian kompensasi memiliki nilai $\beta_{4}$ negatif lebih besar daripada nol sebesar -0,147 dengan nilai signifikansi lebih kecil dari 0,05 sebesar 0,045. Nilai tersebut menujukan bahwa $\mathrm{H}_{4}$ diterima, yang artinya kesesuaian kompensasi berpengaruh negatif dan signifikan terhadap kecuragan akuntansi.

Berdasarkan hasil pengujian pada Tabel3diketahui bahwa $\beta_{1}=0,620$ dengan tingkat signifikansi 0,000 lebih kecil dari $\alpha=0,05$. Artinya variabel perilaku oportunistik berpengaruh positif dan signifikan pada kecurangan akuntansi. Hasil ini menerima hipotesis pertama $\left(\mathrm{H}_{1}\right)$ yang menyatakan bahwa perilaku oportunistik berpengaruh positif pada kecurangan akuntansi. Semakin tinggi perilaku oportunistik yang dimiliki pegawai, maka akan semakin tinggi pula kecurangan yang dilakukan. Perilaku oportunistik merupakan perilaku individu untuk berusaha mengambil keuntungan bagi diri sendiri tanpa mempedulikan 
prinsip - prinsip yang berlaku. Perilaku oportunistik dapat juga digolongkan sebagai perilaku yang cenderung memanipulasi informasi. Perilaku oportunistik cenderung memanipulasi informasi sehingga satu agen mendapatkan informasi yang tidak akurat.

Suatu kecurangan muncul karena adanya peluang untuk mendapatkan keuntungan pribadi pada proyek-proyek yang akan dibiayai dengan anggaran. Perilaku oportunistik didukung oleh teori keagenan dimana bila agen dan principal berusaha untuk memaksimalkan utilitasnya masing-masing, serta memiliki keinginan dan motivasi berbeda, maka agen akan cenderung tidak selalu bertindak sesuai dengan principal. Penelitian sebelumnya menemukan bahwa perilaku oportunistik berpengaruh positif terhadap kecenderungan kecurangan akuntansi (Prakasa, 2016). Sari \& Meiranto (2017) menemukan hasil yang sama yaitu adanya pengaruh positif perilaku oportunistik terhadap peningkatan perilaku kecurangan akuntansi.

Berdasarkan hasil pengujian pada Tabel 3 diketahui bahwa $\beta_{2}=0,375$ dengan tingkat signifikansi 0,007 lebih kecil dari $a=0,05$. Artinya variabel asimetri informasi berpengaruh positif dan signifikan pada kecurangan akuntansi. Hasil ini menerima hipotesis kedua $\left(\mathrm{H}_{2}\right)$ yang menyatakan bahwa asimetri informasi berpengaruh positif pada kecurangan akuntansi. Hal ini memberikan penjelasan bahwa dengan adanya kesenjangan informasi yang terjadi antara principal dan agen akan meningkatkan terjadinya kecurangan akuntansi.

Asimetri informasi terjadi ketika hanya pihak internal instansi yang mengetahui isi dan angka yang sebenarnya dari laporan keuangan yang disusun (Najahningrum, 2013). Kesenjangan informasi antara pihak pengelola dan pihak pemakai berkaitan dengan pembuatan laporan keuangan instansi publik.

Hal ini dikarenakan asimetri informasi merupakan ketidakseimbangan informasi yang dimiliki oleh principal dan agen, ketika principal tidak memiliki informasi yang cukup tentang kinerja agen, sebaliknya justru agen memiliki lebih banyak informasi mengenai kapasitas diri, lingkungan kerja dan instansi secara keseluruhan (Ariani \& Lucy Sri Musmini, 2014). Hal ini membuat manajemen (agen) berpikir untuk mengubah angka akuntansi agar dapat digunakan untuk memaksimalkan kepentingannya. Menurut Ariani \& Lucy Sri Musmini, (2014) menyatakan bahwa asimetri informasi berpengaruh positif terhadap kecurangan akuntansi. Najahningrum, (2013) menyatakan bahwa apabila terjadi kesenjangan informasi antara pihak pengguna dan pihak pengelola, maka akan membuka peluang bagi pihak pengelola dana untuk melakukan kecurangan.

Berdasarkan hasil pengujian pada Tabel 3 diketahui bahwa $\beta_{2}=0,192$ dengan tingkat signifikansi 0,950 lebih besar dari $\alpha=0,05$. Artinya variabel moralitas manajemen tidak berpengaruh negatif dan signifikan pada kecurangan akuntansi. Hasil penelitian menunjukkan menolak menerima hipotesis ketiga $\left(\mathrm{H}_{3}\right)$ yang menyatakan moralitas manajemen berpengaruh negatif pada kecurangan akuntansi. Hal ini memberikan penjelasan bahwa moralitas manajemen yang ada pada instansi tidak memberi pengaruh apapun pada kecurangan akuntansi. Hasil penelitian ini tidak mendukung penelitianpenelitian sebelumnya yaitu Rahmawati (2012) menemukan bahwa semakin 
tinggi moralitas suatu manajemen berpengaruh negatif signifikan terhadap kecenderungan kecurangan akuntansi. Penelitian lain juga menemukan bahwa moralitas manajemen berpengaruh negatif terhadap kecurangan akuntansi pada BUMN Padang (Sanuari, 2014). Safitri (2017) juga menemukan adanya pengaruh negatif moralitas manajementerhadap kecurangan akuntansi pada pegawai BUMN di Daerah Istimewa Yogyakarta. Dimana menyebutkan bahwa adanya pengaruh negatif moralitas manajemen pada kecurangan akuntansi.

Hasil penelitian ini ternyata mendukung penelitian terdahulu lainnya yaitu penelitian Alou et al., (2017) yang juga menemukan bahwa tidak adanya pengaruh moralitas manajemen terhadap tindak kecurangan akuntansi yang dilakukan pada perusahaan konstruksi. Astuti (2017) yang menemukan bahwa moralitas tidak berpengaruh terhadap kecederungan kecurangan akuntansi yang terjadi pada LPD di Kabupaten Buleleng. Hal ini juga ditemukan kembali oleh Sholehah et al., (2018) menemukan bahwa moralitas manajemen tidak memiliki pengaruh yang signifikan terhadap tindakan fraud yang dilakukan pada OPD Provinsi Gorontalo.

Hasil penelitian ini dapat terjadi karena adanya faktor lain yang berada di antara dua variabel ini yaitu antara variabel moralitas manajemen dengan kecurangan akuntansi. Salah satu faktor tersebut adalah pengendalian internal. COSO (1992) dalam Damayanti (2016) Pengendalian internal adalah kebijakan dan prosedur yang disusun oleh manajemen agar dapat mengetahui sasaran dan tujuan perusahaan yang tercapai. Pengendalian internal dibentuk kolektif berdasar kebijakan dan prosedur. Pengendalian internal digunakan untuk mencegah kerugian atau kecurangan. Damayanti (2016) menyebutkan bahwa adanya faktor pengendalian internal yang berpengaruh antara moralitas manajemen dan kecurangan akuntansi. Pengendalian internal ditemukan mampu menekan keinginan untuk melakukan kecurangan akuntansi pada individu dengan moralitas rendah, sehingga yang seharusnya individu dengan moralitas rendah kecenderungan melakukan tindak kecurangan namun dengan adanya pengendalian internal individu cenderung menekan keinginan melakukan tindak kecurangan tersebut.

Berdasarkan hasil pengujian pada Tabel 3 diketahui bahwa $\beta_{3}=-0,192$ dengan tingkat signifikansi sebesar 0, 045 lebih kecil dari $a=0,05$. Artinya variabel kesesuaian kompensasi berpengaruh negatif dan signifikan pada kecurangan akuntansi. Hasil ini menerima hipotesis keempat $\left(\mathrm{H}_{4}\right)$ yang menyatakan bahwa kesesuaian kompensasi berpengaruh negatif pada kecurangan akuntansi. Hal ini menjelaskan bahwa adanya kompensasi yang sesuai dengan pangkat dan golongan tidak memengaruh pada adanya kecurangan akuntansi yang terjadi.

Kompensasi yang diterima pegawai harus sesuai dengan kontribusi yang diberikan pegawaikepada organisasi. Pemberian kompensasi yang sesuai kepada pegawai dapat memberikan kepuasan dan motivasi kepada pegawai dalam bekerja, sehingga mendorong mereka untuk memberikan yang terbaik bagi instansi tempat mereka bekerja. Pernyataan tersebut didukung oleh penelitian sebelumnya yang dilakukan oleh Shintadevi (2016) dan Delfi et al., (2014) yang menyatakan bahwa kesesuaian kompensasi berpengaruh negatif terhadap kecenderungan kecurangan akuntansi. Oktavia (2016) juga menemukan bahwa 
adanya pengaruh negatif dari kompensasi terhadap kecurangan akuntansi yang terjadi pada instansi.

Penelitian ini diharapkan dapat memberikan tambahan bukti empiris yang hasilnya dapat memperkuat mengenai teori keagenan dalam menjelaskan hubungan pengaruh perilaku oportunistik, asimetri informasi, moralitas manajemen dan kesesuaian kompensasi pada kecurangan akuntansi di Pemerintah Daerah Kabupaten Jembrana. Hal ini mendukung teori keagenan yang memandang bahwa pemerintah daerah sebagai agen bagi masyarakat (principal) akan bertindak dengan penuh kesadaran bagi kepentingan mereka sendiri serta memandang bahwa pemerintah daerah tidak dapat dipercaya untuk bertindak dengan sebaik-baiknya bagi kepentingan masyarakat. Teori keagenan beranggapan bahwa tingginya asimetri informasi yang terjadi antara pihak agen (pemerintah) yang mempunyai akses langsung terhadap informasi dengan pihak prinsipal (masyarakat). Hal ini membuktikan bahwa perilaku oportunistik dan dengan adanya asimetri informasi yang terjadi maka perilaku kecurangan akuntansi akan meningkat.

Penelitian ini menunjukkan bahwa perilaku oportunistik dan asimetri informasi dengan tingkat yang tinggi akan meningkatkan perilaku kecurangan akuntansi. Hal tersebut mendukung teori keagenan dalam penelitian ini yaitu bagaimana asimetri informasi mempengaruhi tingkat kecurangan akuntansi yang terjadi dalam organisasi.

Selain dua variabel yang dibahas sebelumnya, kesesuaian kompensasi yang diberikan juga berpengaruh negatif terhadap perilaku kecurangan akuntansi. Hal ini berarti dengan kompensasi yang sesuai mampu mengurangi perilaku kecurangan akuntansi yang terjadi. Temuan ini dapat terjadi karena kompensasi dengan pemberian yang tepat akan menghasilkan kepuasan kerja bagi pegawai. Kepuasan kerja akan mengurangi perilaku menyimpang seperti perilaku kecurangan akuntansi.

Hasil penelitian ini dapat digunakan sebagai kontribusi bagi OPD bagian Keuangan Kabupaten Jembrana dalam mempengaruhi motivasi mereka terkait dengan menurunkan praktik kecurangan akuntansi dengan memperhatikan perilaku oportunistik, mencegah asimetri informasi yang terjadi, serta pengaturan kompensasi yang sesuai di OPD Kabupaten Jembrana. Selain itu, hasil penelitian ini juga diharapkan dapat menjadi suatu dukungan terhadap terciptanya OPD yang bersih dan terbebas dari kecurangan akuntansi di Pemerintahan Kabupaten Jembrana.

\section{SIMPULAN}

Perilaku oportunistik berpengaruh positif pada kecurangan akuntansi di Pemerintah Daerah Kabupaten Jembrana. Hal ini bermakna bahwa semakin tinggi perilaku oportunistik yang dimiliki maka semakin tinggi tingkat kecurangan yang akan terjadi.Asimetri informasi berpengaruh positif pada kecurangan akuntansi di Pemerintah Daerah Kabupaten Jembrana. Hal ini bermakna bahwa semakin tinggi kesenjangan informasi yang terjadi akan semakin tinggi kecurangan terjadi.Moralitas manajemen tidak berpengaruh negatif pada kecurangan akuntansi di Pemerintah Daerah di Kabupaten Jembrana. Semakin tinggi ataupun rendah moralitas manajemen tidak 
berpengaruh terhadap kecurangan akuntansi.Kesesuaian kompensasi berpengaruh negatif pada kecurangan informasi pada Pemerintah Daerah di Kabupaten Jembrana. Hal ini bermakna bahwa semakin tinggi kompensasi yang diterima tidak mempengaruhi kecurangan yang terjadi.

Penelitian ini diharapkan dapat memberikan gambaran bagi OPD Kabupaten Jembrana bahwa untuk menekan kasus kecurangan laporan akuntansi perlu untuk memperhatikan beberapa faktor yang mempengaruhi kecurangan itu sendiri. Pertama, menekan perilaku oportunistik pada pegawai OPD sehingga akan mengurangi kecenderungan mereka mencari keuntungan dari mencurangi laporan akuntansi. Kedua mencegah terjadi asimetri informasi yang terjadi sehingga informasi yang tepat dapat terjadi antara kedua belah pihak sehingga tidak terjadi kecurangan laporan akuntansi. Ketiga dengan memperhatikan pemberian kompensasi yang tepat bagi pegawai pada OPD Kabupaten Jembrana sehingga diharapkan dengan kompensasi yang lebih tepat dan adil maka menghindari keinginan pegawai OPD Kabupaten Jembrana melakukan kecurangan akuntansi.

Hasil penelitian ini diharapkan dapat memberikan kontribusi dan tambahan pengetahuan dalam pengembangan teori-teori yang sesuai dengan penelitian yang dilakukan. Bagi peneliti selanjutnya yang tertarik untuk melakukan penelitian sejenis, disarankan untuk meneliti dengan menggunakan variabel yang berbeda yang dapat berpengaruh terhadap kecurangan laporan akuntansi.

\section{REFERENSI}

Adiputra, I Made Pradana , Dwiyantari, Ni Kadek Desi , Darmada, D. K. (2014). Pengaruh PAD, Dana Perimbangan dan SiLPA Terhadap Kualitas Pembangunan Manusia Dengan Alokasi Belanja Modal Sebagai Variabel Intervening (Studi Pada Pemerintah Kabupaten/Kota di Bali). Simposium Nasional Akuntansi, 18.

Alou, S. D., Ilat, V., \& Gamaliel, H. (2017). Pengaruh Kesesuaian Kompensasi, Moralitas Manajemen, dan Keefektifan Pengendalian Internal terhadap Kecenderungan Kecurangan Akuntansi pada Perusahaan Konstruksi di Manado. JurnalRiset Akuntansi Going Concern , 12(01).

Ariani, K. S., \& Lucy Sri Musmini, N. T. H. (2014). Analisis Pengaruh Moralitas Individu, Asimetri Informasi dan Keefektifan Sistem Pengendalian Internal Terhadap Kecenderungan Kecurangan Akuntansi Di PDAM Kabupaten Bangli. JIMAT (Jurnal Ilmiah Mahasiswa Akuntansi) Undiksha, 2(1).

Astrid, K. (2015). Interaksi Moralitas Individu dan Kesesuaian Kompensasi Pada Kecurangan Akuntansi (Studi Eksperimen Pada Pemerintah Kota Denpasar). Tesis. Universitas Udayana.

Astuti, N. K. A. T. (2017). Pengaruh Moralitas Individu, Ketaatan Aturan Akuntansi, dan Efektivitas Pengendalian Internal terhadap Kecenderungan Kecurangan (Fraud) Akuntansi pada Lembaga Perkreditan Desa di Kabupaten Buleleng. JIMAT (Jurnal Ilmiah Mahasiswa Akuntansi) Undiksha, $8(2)$.

Delfi, T., Anugerah, R., \& A, A. (2014). Pengaruh efektifitas pengendalian internal dan kesesuaian kompensasi terhadap kecenderungan kecurangan akuntansi (Survey pada perusahaan BUMN cabang Pekanbaru). Jurnal Online 
Mahasiswa (JOM) Bidang Ilmu Ekonomi, 1(2).

Dito, A. H., \& Lataruva, E. (2010). Pengaruh Kompensasi Terhadap Kinerja Karyawan PT. Slamet Langgeng Purbalingga Dengan Motivasi Kerja Sebagai Variabel Intervening. Tesis. Universitas Diponogoro.

Eisenhardt, K. M. (1989). Agency Theory: An Assessment and Review. The Academy of Management Review, 14(1). https:/ / doi.org/10.2307/258191

Handoko, J. (2014). Pengaruh Sistem Pengendalian Internal, Sistem Kompensasi dan Moralitas Manajemen Terhadap Kecenderungan Kecurangan Akuntansi. Skripsi. Universitas Katolik Widya.

Keraf, A. S. (1998). Etika bisnis : tuntutan dan relevansinya. (3ed). Jakarta: Kanisius.

Lestari, N. K. L., \& Supadmi, N. L. (2017). Pengaruh Pengendalian Internal, Integritas, dan Asimetri Informasi pada Kecuragan Akuntansi (pada Organisasi Perangkat Daerah Di Kabupaten Klungkung). E-Jurnal Akuntansi Universitas Udayana, 389-417.

Maroney, J. J., \& McDevitt, R. E. (2008). The Effects of Moral Reasoning on Financial Reporting Decisions in a Post Sarbanes-Oxley Environment. Behavioral Research in Accounting, 20(2). https://doi.org/10.2308/bria.2008.20.2.89

Mustikasari, D. P. (2013). Persepsi Pegawai Dinas Se-Kabupaten Batang Tentang Faktor-Faktor Yang Mempengaruhi Kecurangan (Fraud). Tesis. Universitas Negeri Semarang.

Najahningrum, A. F. (2013a). Faktor-Faktor yang Mempengaruhi Fraud: Persepsi Pegawai Dinas Provinsi DIY. Accounting Analysis Journal.

Najahningrum, A. F. (2013b). Faktor-Faktor Yang Mempengaruhi

Kecenderungan Kecurangan (Fraud): Persepsipegawai Dinas Provinsi Diy. Tesis.Universitas Negeri Semarang.

Oktavia,Trisna Ayu , Yosefa Sayekti, W. P. (2016). Centrality metrics and linegraph to measure the importance of links in online social networks. International Journal of New Technology and Research, 4(6).

Oktavia. (2016). The Effect of Compensation to Detection Fraud in Village Government (Empirical Study on Sub-District of Pasirian, District Of Lumajang). International Journal of New Technology and Research, 4(6).

Pradana, Adiputra, et al. (2014). Pengaruh Integritas, Obyektivitas, dan Akuntabilitas Terhadap Kualitas Audit Di Pemerintah Daerah 9Studi Pada Inspektorat Kabupaten Buleleng). JIMAT (Jurnal Ilmiah Mahasiswa Akuntansi) Undiksha, 2(1).

Prakasa, A. (2016). Pengaruh Perilaku Oportunistik, Etika Dan Komitmen Organisasi Legislatif Terhadap Senjangan Anggaran Pada Anggaran Pendapatan dan Belanja Daerah (APBD) Studi pada Anggota Dewan Perwakilan Rakyat Daerah (DPRD) Wilayah Provinsi Daerah Istimewa Yogyakarta (DIY) Periode 2014-2019. Skripsi. Universitas Islam Indonesia.

Putra, I. N. W. A. (2011). Manajemen Laba: Perilaku Manajemen Oportunistik Atau Realistic? Jurnal Ilmiah Akuntansi Dan Bisnis. Retrieved from

Rahmawati, P. A. (2012). Analisis Pengaruh Faktor Internal dan Moralitas Manajemen Terhadap Kecenderungan Akuntansi (Studi Pada Dinas Pengelola Keuangan Dan Aset Daerah Kota Semarang). Skripsi. Fakultas Ekonomika Dan Bisnis Universitas Diponogoro. 
Safitri, D. (2017). Faktor Faktor Yang Mempengaruhi Penerapan Standar Akuntansi Pemerintahan Berbasis Akrual (Studi Pada SKPD Pemerintah Kabupaten Bengkalis). Jurnal Akuntansi (Media Riset Akuntansi \& Keuangan), $5(2)$.

Sanuari, N. (2014). Pengaruh Sistem Pengendalian Internal, Kesesuaian Kompensasi, Dan Moralitas Manajemen Terhadap Kecenderungan Kecurangan Akuntansi (studi empiris pada Kantor BUMN Kota Padang). Jurnal Akuntansi, 2(1).

Sari, A. R., \& Meiranto, W. (2017). Pengaruh Perilaku Oportunistik, Mekanisme Pengawasan, dan Financial Distress Terhadap Manajemen Laba. Diponegoro Journal of Accounting, 6(4).

Setiawan, M. D., \& Adiputra, I. M. P. (2015). Pengaruh Sistem Pengendalian Intern, Asimetri Informasi, Dan Keadilan Organisasi Terhadap Kecurangan (Fraud)(Studi Empiris pada Bank Perkreditan Rakyat Se-Kabupaten Buleleng). JIMAT (Jurnal Ilmiah Mahasiswa Akuntansi) Undiksha, 3(1).

Shintadevi, P. F. (2016). Pengaruh Keefektifan Pengendalian Internal, Ketaatan Aturan Akuntansi dan Kesesuaian Kompensasi Terhadap kecenderungan Kecurangan Akuntansi Dengan Perilaku Tidak Etis Seagai Variabel Intervening. Nominal, Barometer Riset Akuntansi Dan Manajemen, 4(2). https://doi.org/10.21831/nominal.v4i2.8003

Sholehah, N. L. H., Rahim, S., \& Muslim, M. (2018). Pengaruh Pengendalian Internal, Moralitas Individu dan Personal Culture Terhadap Kecurangan Akuntansi (Studi Empiris Pada OPD Provinsi Gorontalo). ATESTASI : Jurnal Ilmiah Akuntansi, 1(1).

Soepardi, E. M. (2007). Upaya Pencegahan Fraud dalam Pengelolaan Keuangan Negara. Economics Business \& Accounting Review, 2(1), 22-34.

Sri Damayanti, D. N. (2016). Pengaruh Pengendalian Internal dan Moralitas Individu Terhadap Kecurangan Akuntansi. Nominal, Barometer Riset Akuntansi Dan Manajemen, 5(2). https://doi.org/10.21831/nominal.v5i2.11725

Waworuntu, B. (2003). Determinan Kepemimpinan. Makara Hubs-Asia, 7(2). Wilopo. (2006). Analisis Faktor-faktor yang Berpengaruh Terhadap Kecenderungan Kecurangan Akuntansi: Studi pada Perusahaan Publik dan Badan Usaha Milik Negara di Indonesia. The Indonesian Journal of Accounting Research, 9(3). https://doi.org/10.33312/IJAR.163

Yakovleva, E., Grigoryeva, N., \& Grigoryeva, O. (2016). Opportunistic Behavior as Behavior Manipulations. American Journal of Applied Sciences, 13(9). https://doi.org/10.3844/ajassp.2016.996.1005 